\title{
Copepods Boost the Production but Reduce the Carbon Export Efficiency by Diatoms
}

\author{
Brivaëla Moriceau ${ }^{1 *}$, Morten H. Iversen ${ }^{2}$, Morgane Gallinari ${ }^{1}$, Antti-Jussi O. Evertsen ${ }^{3}$, \\ Manon Le Goff ${ }^{1}$, Beatriz Beker ${ }^{1}$, Julia Boutorh ${ }^{1}$, Rudolph Corvaisier ${ }^{1}$, Nathalie Coffineau ${ }^{1}$, \\ Anne Donval ${ }^{1}$, Sarah L. C. Giering ${ }^{4}$, Marja Koski ${ }^{5}$, Christophe Lambert ${ }^{1}$, \\ Richard S. Lampitt ${ }^{4}$, Alain Le Mercier ${ }^{1}$, Annick Masson ${ }^{1}$, Herwig Stibor ${ }^{6}$, \\ Maria Stockenreiter ${ }^{6}$ and Christina L. De La Rocha ${ }^{1}$

\begin{abstract}
${ }^{1}$ Laboratoire des Sciences de l'environnement Marin (LEMAR) UMR6539 CNRS/UBO/IFREMER/IRD, Université de Bretagne Occidentale, Institut Universitaire Européen de la Mer (IUEM), Technopole Brest-Iroise, Plouzané, France, ${ }^{2}$ Alfred Wegener Institute for Polar and Marine Research, MARUM, University of Bremen, Bremen, Germany, ${ }^{3}$ Department of Biology, Norwegian University of Science and Technology, Trondheim, Norway, ${ }^{4}$ National Oceanography Centre Southampton, Natural Environment Research Council, University of Southampton, Southampton, United Kingdom, ${ }^{5}$ Institute for Aquatic Resources (DTU Aqua), Technical University of Denmark, Charlottenlund, Denmark, ${ }^{6}$ Biology II, Aquatic Ecology,

Ludwig-Maximilians-Universität München, Planegg-Martinsried, Germany
\end{abstract}

OPEN ACCESS

Edited by: Eric 'Pieter Achterberg, GEOMAR Helmholtz Centre for Ocean Research Kiel, Germany

Reviewed by: Jan Taucher, GEOMAR Helmholtz Centre for Ocean Research Kiel, Germany Javier Arístegui, University of Las Palmas de Gran Canaria, Spain

*Correspondence: Brivaëla Moriceau moriceau@univ-brest.fr

Specialty section: This article was submitted to Marine Biogeochemistry, a section of the journal Frontiers in Marine Science

Received: 08 August 2017 Accepted: 26 February 2018 Published: 22 March 2018

Citation:

Moriceau B, Iversen $M H$, Gallinari $M$ Evertsen A-JO, Le Goff M, Beker B, Boutorh J, Corvaisier R, Coffineau N,

Donval A, Giering SLC, Koski M, Lambert C, Lampitt RS, Le Mercier A, Masson A, Stibor H, Stockenreiter M and De La Rocha CL (2018) Copepods Boost the Production but Reduce the Carbon Export Efficiency

by Diatoms. Front. Mar. Sci. 5:82. doi: 10.3389/fmars.2018.00082
The fraction of net primary production that is exported from the euphotic zone as sinking particulate organic carbon $(\mathrm{POC})$ varies notably through time and from region to region. Phytoplankton containing biominerals, such as silicified diatoms have long been associated with high export fluxes. However, recent reviews point out that the magnitude of export is not controlled by diatoms alone, but determined by the whole plankton community structure. The combined effect of phytoplankton community composition and zooplankton abundance on export flux dynamics, were explored using a set of 12 large outdoor mesocosms. All mesocosms received a daily addition of minor amounts of nitrate and phosphate, while only 6 mesocosms received silicic acid (dSi). This resulted in a dominance of diatoms and dinoflagellate in the $+\mathrm{Si}$ mesocosms and a dominance of dinoflagellate in the $-\mathrm{Si}$ mesocosms. Simultaneously, half of the mesocosms had decreased mesozooplankton populations whereas the other half were supplemented with additional zooplankton. In all mesocosms, POC fluxes were positively correlated to $\mathrm{Si} / \mathrm{C}$ ratios measured in the surface community and additions of dSi globally increased the export fluxes in all treatments highlighting the role of diatoms in $\mathrm{C}$ export. The presence of additional copepods resulted in higher standing stocks of POC, most probably through trophic cascades. However it only resulted in higher export fluxes for the $-\mathrm{Si}$ mesocosms. In the $+\mathrm{Si}$ with copepod addition (+Si $+\mathrm{Cops}$ ) export was dominated by large diatoms with higher $\mathrm{Si} / \mathrm{C}$ ratios in sinking material than in standing stocks. During non-bloom situations, the grazing activity of copepods decrease the export efficiency in diatom dominated systems by changing the structure of the phytoplankton community and/or preventing their aggregation. However, in flagellate-dominated system, the copepods increased phytoplankton growth, aggregation and fecal pellet production, with overall higher net export not always visible in term of export efficiency.

Keywords: biogenic silica, POC, marine snow, zooplankton, mesocosm, Bay of Hopavågen, plankton community, biological pump 


\section{INTRODUCTION}

The export of particulate organic carbon (POC) from the surface ocean, in terms of the overall amount or as the fraction of local net primary production, varies seasonally as well as regionally (Lutz et al., 2002; Boyd and Trull, 2007; Honjo et al., 2008; Buesseler and Boyd, 2009; Lam et al., 2011; Henson et al., 2012; Siegel et al., 2016). Numerous factors intervene in this variability: turbulence, stratification, and mixed layer depth; phytoplankton community composition; the rates, timing, and extent of seasonality of primary production; meso- and microzooplankton abundance and feeding strategies; the aggregation of particulate organic matter (POM) into large, rapidly sinking particles of marine snow; and the occurrence of ballast particles like biogenic silica, calcium carbonate, and dust. The actions and interactions of these factors determine the ocean food web, which either recycles most of the organic matter in the surface ocean (resulting in only minor export to depth) or is "leaky" (exporting a large portion of the net primary production to depth). It is necessary to understand food web interactions in order to predict the biological pump's variability and its ability to sequester $\mathrm{CO}_{2}$ in a future ocean with warmer temperatures, higher $\mathrm{CO}_{2}$, more acidity, and differing nutrient inputs and ratios compared to the present ocean (Bopp, 2005; Passow and Carlson, 2012; Alvain et al., 2013; Bopp et al., 2013).

Relationships between food webs, ballast minerals and fluxes have been investigated in various physical regimes. On the smaller scale of such investigations are microcosm studies of sinking particles in rolling tanks (Shanks and Trent, 1980; Passow and De La Rocha, 2006) and flow through systems (Ploug et al., 2008; Long et al., 2015) that allow controlled examination of selected processes and interactions. At the other extreme are regional and global scale studies based on models, remote sensing, and observational data from time-series, cameras, autonomous platforms, and sediment traps (Klaas and Archer, 2002; Honjo et al., 2008; Klaas et al., 2008; Lee et al., 2009; Lam et al., 2011; Assmy et al., 2013; Quéguiner, 2013; Giering et al., 2014; Sanders et al., 2014; Guidi et al., 2016). However, whereas small scale laboratory investigations allow full control over environmental variables and mechanistic investigations, they often lack natural community composition. Field studies allow identification of larger scale patterns and correlations with environmental variables but no clear identification of causal relationships owing to complex confounding factors. Mesocosms offer a middle ground, where some of the control of small scale laboratory experiments is combined with parts of the complexity of environmental variables of field observations. Mesocosms enclose part of an in situ water column allowing manipulations of target parameters. Mesocosms are large enough to host a reasonably complex food web (e.g., including microand mesozooplankton) (Wassmann et al., 1996; Svensen et al., 2001; Sommer et al., 2004; Stibor et al., 2004; Olsen et al., 2006; Stange et al., 2017) while still allow controlled manipulations of parameters such as nutrients, ballast minerals, turbulence, and phytoplankton and zooplankton community composition.

A small number of mesocosm experiments have been used to study phytoplankton community interactions and POC export.
Early work noted a strong link between the addition of silicic acid (in addition to nitrate and phosphate) and POC export fluxes (Wassmann et al., 1996). It was hypothesized that the addition of silicic acid promoted the growth of diatoms, which increased export of POC (Engel et al., 2002; Kemp et al., 2006; Kemp and Villareal, 2013; Rynearson et al., 2013; Lasbleiz et al., 2014). However, later studies showed that artificial mixing of upper water layers also initiated aggregate formation even in the absence of diatoms, suggesting that diatoms (and indirectly silicic acid) were not the sole trigger of high POC fluxes (Svensen et al., 2001, 2002). Several factors could results in high POC export, including phytoplankton aggregation of both diatom and non-diatom phytoplankton and zooplankton grazing, suggesting that the whole plankton community structure - more than just presence of diatoms-is important to determine export fluxes (Gehlen et al., 2006; Guidi et al., 2016).

Generally carbon export follows the seasonality of primary production but is even more dependent on the fraction of slowsinking versus fast-sinking aggregates, with higher export for fast sinking aggregates (Moriceau et al., 2007; Henson et al., 2015). However, the influence of seasonality and plankton community composition on global export efficiency (proportion of primary production that is transported below the mixed layer depth) is still poorly understood. Except for recent studies on the impact of acidification or elevated $\mathrm{CO}_{2}$ concentrations (Paul et al., 2015; Bach et al., 2016; Spilling et al., 2016; Gazeau et al., 2017) most mesocosms studies have focused on the processes that lead to export during phytoplankton bloom conditions, even though non-blooming periods can potentially be important for global export fluxes, and can be periods of efficient export of carbon and $\mathrm{bSiO}_{2}$ (Fujii and Chai, 2005; Morris et al., 2007; Lam et al., 2011). Efficient export during non-bloom conditions has been linked to zooplankton abundance, which can repackage small particles into dense, fast-sinking particles (Lalande et al., 2016).

We designed a mesocosm study to investigate the link between plankton composition and export flux during non-blooming conditions. We explicitly tested the impact of zooplankton abundance on export fluxes for two different phytoplankton populations.

\section{MATERIALS AND METHODS Study Area}

The experiment was conducted in 2012, between August 2 and 24 in the Bay of Hopavågen ( $\left.63^{\circ} 36^{\prime} \mathrm{N}, 9^{\circ} 33^{\prime} \mathrm{E}\right)$, a tidally-driven, semi-enclosed marine lagoon on the west coast of Norway, $20 \mathrm{~km}$ west of the outlet of the Trondheimsfjord (Figure 1). This semienclosed marine lagoon has a maximum depth of $32 \mathrm{~m}$, a volume of roughly $6.7 \times 10^{6} \mathrm{~m}^{3}$, and exchanges roughly $14 \%$ of its water daily with the ocean through a narrow inlet (van Marion, 1996).

Nutrient concentrations in the lagoon at the time of the experiment were extremely low $(<1 \mu \mathrm{M}$ for silicic acid, $<0.3 \mu \mathrm{M}$ for ammonium, and $<0.1 \mu \mathrm{M}$ for nitrate, nitrite, and phosphate). Concentrations of chlorophyll a (Chl) in the upper $10 \mathrm{~m}$ of the lagoon at the time of the experiment ranged from 0.5 to $2.4 \mathrm{mg} \mathrm{m}^{-3}$, corresponding well to the typical average summer 


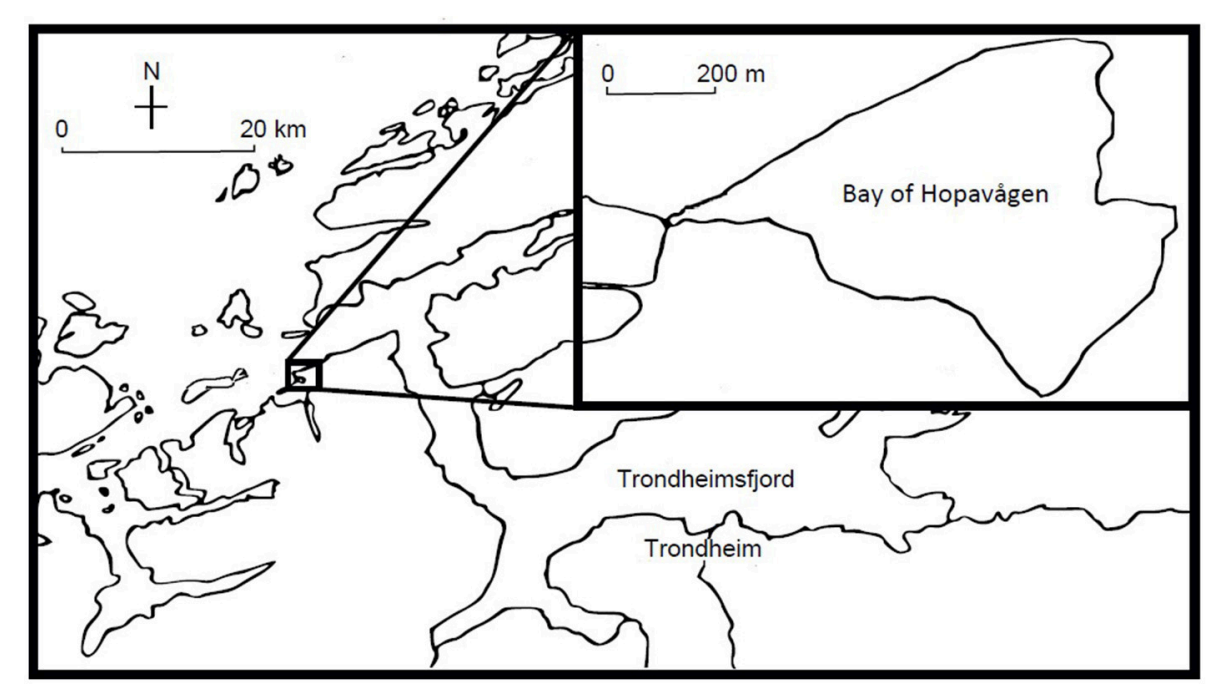

FIGURE 1 | The Bay of Hopavågen.

concentrations for this lagoon (between $1-3 \mathrm{mg} \mathrm{m}^{-3}$, Olsen et al., 2006).

Mesozooplankton commonly found in the Bay of Hopavågen include the ctenophore Bolinopsis sp., calanoid copepods (such as Temora sp., Centropages sp., and Pseudocalanus sp.) at an average summer concentration of 20 ind $\mathrm{L}^{-1}$, the cyclopoid copepod Oithona sp., and the appendicularian Okipleura sp. (van Marion, 1996; Stibor et al., 2004; Vadstein et al., 2004). The phytoplankton community in the lagoon consists of diatoms (e.g., Rhizosolenia sp., Skeletonema sp., Thalassiosira sp., Nitzschia sp., and Pseudonitzschia sp.), autotrophic picoplankton, dinoflagellates (e.g., Gymnodinium sp., Prorocentrum sp.), and nanoflagellates (Sommer et al., 2005).

\section{Mesocosms}

Each mesocosm consisted of a $10 \mathrm{~m}$ deep polyethylene tube, with a diameter of approximately $1 \mathrm{~m}$, a volume of roughly $9 \mathrm{~m}^{3}$, and a sealed, conical bottom. The twelve mesocosms were filled on August 2 by lowering the entire mesocosm bag to a depth of $10 \mathrm{~m}$ and then raising the top gently back up to the surface. The filled mesocosms were secured to a raft that was anchored in the deepest part of the Bay of Hopavågen.

The light conditions in each mesocosm were similar, with light intensities of $15-20 \%$ of surface light at $1 \mathrm{~m}$ depth (generally around $100 \mu \mathrm{mol} \mathrm{m}^{-2} \mathrm{~s}^{-1}$ ) and $\sim 1 \%$ at $\sim 6 \mathrm{~m}$ depth (Figure 2). These conditions were similar to the light intensities observed in the Bay of Hopavågen (around the mesocosms) during the experiment ( $\sim 40 \% \sim 300 \mu \mathrm{mol} \mathrm{m} \mathrm{m}^{-2} \mathrm{~s}^{-1}$ at $1 \mathrm{~m}$ and $8 \%$ at $6 \mathrm{~m}$ ).

To avoid disturbances of formed aggregates within the mesocosms and to avoid interfering with sinking fluxes, the mesocosms were not mixed during the experiment. However, some small-scale mixing and turbulence might have occurred within the mesocosms due to waves and tidal currents within the Bay of Hopavågen during the study. According to the Chl profiles, the upper $2 \mathrm{~m}$ of the mesocosm bags were well-mixed
(Figure 2). Turbulence was not measured during the experiment, but previous work in similar types of mesocosms suggested that the energy dissipation rates in the mesocosms would have been on the order of $10^{-9}-10^{-8} \mathrm{~m}^{2} \mathrm{~s}^{-3}$, corresponding to a wind velocity of 3-6 $\mathrm{m} \mathrm{s}^{-1}$ (Svensen et al., 2001).

In the Bay of Hopavågen, nutrients are resupplied daily by the natural water inflow (Sommer et al., 2004). We mimicked the natural nutrient input by manually adding nutrient to the enclosed mesocosms, using nitrogen concentrations that compensated for the loss of $\mathrm{N}$ caused by sedimentation and Redfield ratios for phosphorus and silicon additions as described in previous studies (Sommer et al., 2005; Olsen et al., 2006). Such nutrients additions maintained the low natural phytoplankton concentrations yet avoided accumulation of unrealistically high concentrations of phytoplankton biomass (Børsheim et al., 2005).

Twelve mesocosms were set up in total, allowing the investigation of four different treatments in triplicate. The treatments were (1) silicate addition and decreased copepod abundance ( $+\mathrm{Si}$-Cops), (2) silicate addition and increased copepod abundance ( $+\mathrm{Si}+\mathrm{Cops})$, (3) no silicate addition and decreased copepod abundance ( $-\mathrm{Si}$-Cops), (4) no silicate addition and increased copepod abundance ( $-\mathrm{Si}+\mathrm{Cops}$ ). Nutrients were added via an 8 -m long tube. The tube was lowered slowly to a depth of $8 \mathrm{~m}$ in each mesocosm and then fully filled with a nutrient solution calculated to add the required concentration of nutrients to each mesocosm. The tube was then slowly lifted out to minimize disturbances of the water in the mesocosms. Through the process of displacement, this allowed the nutrients to distribute evenly throughout the water column of the mesocosms (Olsen et al., 2007). Nutrients uptake are lower in the dark (Dortch and Maske, 1982; Litchman et al., 2004) and samplings were done in the morning. Nutrients were added in the evening to avoid contamination of the morning sampling, and began the day after the bags were filled (on the evening of August 3 ) and 4.5 days before the first day of sampling. Previous 

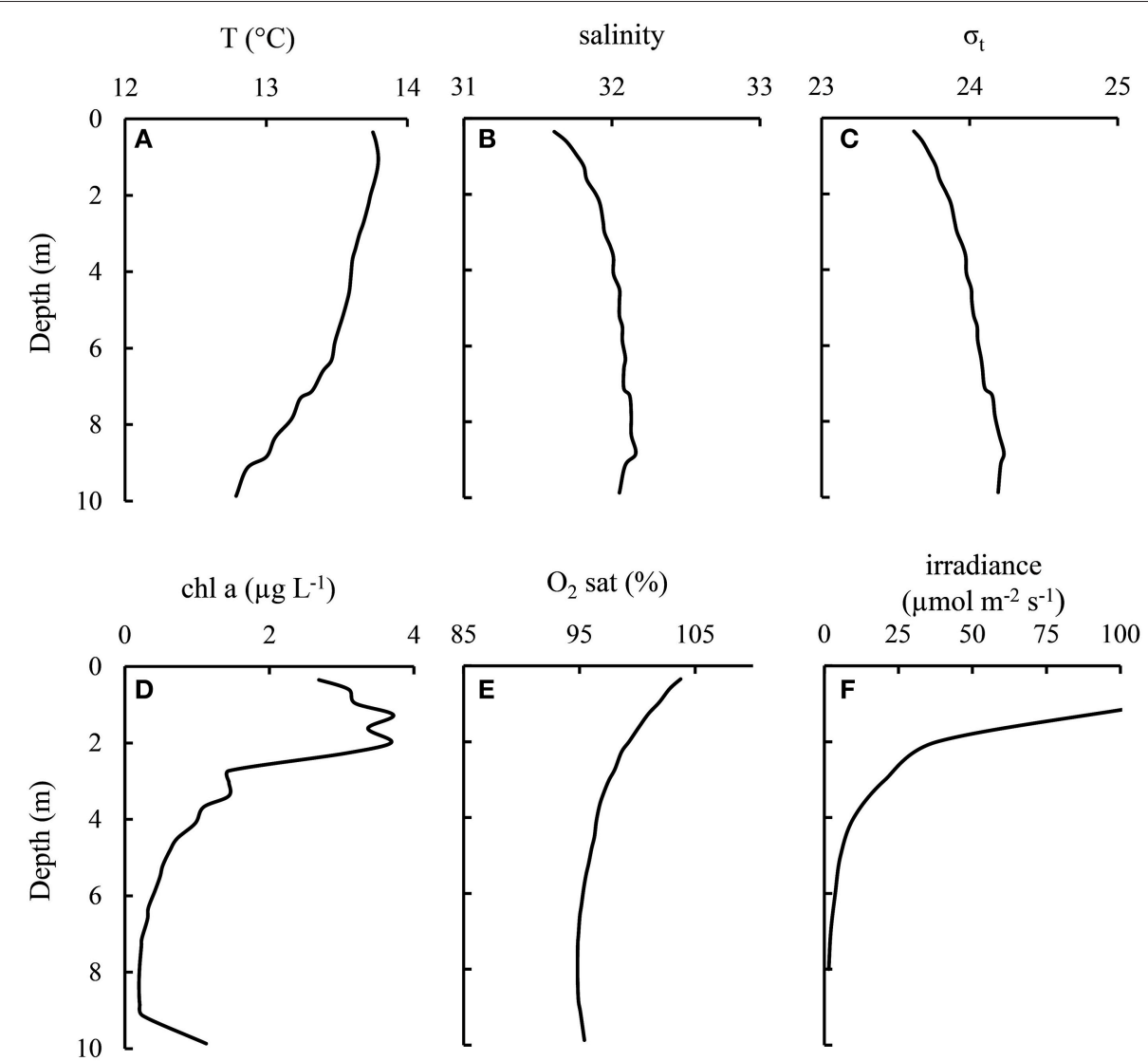

FIGURE 2 | Typical physical conditions within the mesocosms as exemplified by bag 3 (+Si-Cops) on August $23-24$ (experiment Days 16-17).

study evidenced that such a time lag allows the phytoplankton communities to differentiate depending on nutrient additions (Gismervik et al., 2002; Sommer et al., 2004; Larsen et al., 2015).

Following Stibor et al. (2004), mesozooplankton concentrations were reduced in the -Cops treatments by repeated vertical hauls with a $150-\mu \mathrm{m}$ plankton net (Sommer et al., 2004; Stibor et al., 2004). We refer to these mesocosm as ' $+\mathrm{Si}$-Cops' and '-Si - Cops', respectively. In the evening of August 7 (5 days after the filling of the bags and 1 day before the first sampling day), we increased the copepod abundance in the +Cops treatments by adding copepods (4 copepods per liter), mainly Centropages sp. and Oithona sp., collected from the lagoon using a $150-\mu \mathrm{m}$ plankton net.

\section{Sample Collection and Analysis}

Day 1 of the sampling was on the morning of August 8, 5.5 days after filling the bag and 4.5 days after the first nutrient addition. The sampling period lasted 17 days in total. On Days 1, 3, 6, 10, 13 and 16 of the sampling period, depth-integrated samples of the upper $4.5 \mathrm{~m}$ of the mesocosms were collected between 7:00 and 8:00 in the morning. Sampling was done by repeated and slow deployments of a $1 \mathrm{~m}$ long integrated water sampler. We collected a total of $12-20 \mathrm{~L}$ from each mesocosm $(0.1-0.2 \%$ of initial water volume), depending on the sampling strategy of the day. Water samples were placed in opaque $20 \mathrm{~L} \mathrm{LDPE}$ carboys (Nalgene), which were subsampled for total and fractionated particulate organic carbon (POC) and nitrogen (PON), biogenic silica $\left(\mathrm{bSiO}_{2}\right)$, pigments, nutrients, phytoplankton cell counts, and microscopic taxonomy of phytoplankton.

Sinking particles were collected with sediment traps from $8 \mathrm{~m}$ depth three times during the course of the experiment, from Day 3 to Day 8, from Day 9 to Day 12, and from Day 14 to Day 17. This was done with cylindrical sediment traps with an aspect ratio (height to width) of 6 in mesocosms in two of each treatment triplicate. In the four remaining mesocosms (one of each treatment triplicate), we deployed gel traps (McDonnell and Buesseler, 2010) at $8 \mathrm{~m}$ to collect and preserve the size and structure of the sinking particles. The gel traps were only deployed for 2 days in order to avoid individual particles landing on top of each other in the gel. Gel traps were deployed on Day 3, 8 , and 14 .

Phytoplankton community compositions were determined for one of each treatment triplicates (four mesosocosms in total) four times during the sampling period. Water samples were preserved with Lugol's iodine ( $1 \%$ final concentration) and taxonomically identified to species level using an inverted microscope (Utermöhl, 1958). 
Samples for particulate organic carbon (POC) and for particulate organic nitrogen (PON) were filtered onto precombusted $\left(450^{\circ} \mathrm{C}, 5 \mathrm{~h}\right) \quad 25-\mathrm{mm} \quad \mathrm{GF} / \mathrm{F}$ filters $(0.7-\mu \mathrm{m}$ nominal pore size, Whatman). Every second sampling day, POC/PON samples were size fractionated before filtration using different screens. Size fractions were $0.7-2.7,2.7-20,20-44$, $44-100$, and $>100 \mu \mathrm{m}$. Filters were rinsed with MilliQ water to remove salts and dried overnight at $60^{\circ} \mathrm{C}$. Inorganic carbon was removed from the filters by fuming with $\mathrm{HCl}$ before analysis with a Flash 1112 Series elemental CN analyzer (ThermoQuest).

Samples for Chl a were filtered onto GF/F filters $(0.7-\mu \mathrm{m}$ nominal pore size, Whatman) and immediately frozen in liquid nitrogen. The filters were stored at $-80^{\circ} \mathrm{C}$ until analysis by HPLC (Shimadzu LC-10A HPLC system with LC Solution software; Shimadzu). The HPLC system was calibrated with pigment standards (DHI Water and Environment).

Samples for biogenic silica $\left(\mathrm{bSiO}_{2}\right)$ were filtered onto $0.4-\mu \mathrm{m}$ polycarbonate filters (Millipore), dried overnight at $60^{\circ} \mathrm{C}$ and stored at room temperature until digestion and analysis. $\mathrm{bSiO}_{2}$ in the samples was dissolved in $0.2 \mathrm{M} \mathrm{NaOH}$ at $100^{\circ} \mathrm{C}$ for $60 \mathrm{~min}$ (Ragueneau et al., 2005) and neutralized with $1 \mathrm{M} \mathrm{HCl}$ for silicic acid analysis by colorimetry. Particulate $\mathrm{bSiO}_{2}$ concentrations were corrected for lithogenic contribution following a second digestion of the particulate matter to yield the $\mathrm{Si}$ :Al ratio of the lithogenic silica (Ragueneau et al., 2005). Aluminum was determined via inductively coupled plasma optical emissions spectroscopy (ICP-OES).

Samples for nitrate, nitrite, silicic acid, phosphate and ammonium were filtered through $0.4-\mu \mathrm{m}$ polycarbonate filters (Millipore) and analyzed using a Bran+Luebbe AAIII autoanalyzer. Concentrations of ammonium in water samples were measured manually on a spectrophotometer (Shimatzu UV 1700) following Koroleff (1969).

\section{Statistical Analysis}

To test and differentiate the effect of time from the effect of the different treatments: +Si vs. $-\mathrm{Si}$ and +Cops vs. -Cops, a twoway or three-way analysis of variance (ANOVA) with a multiple comparison procedure (Holm-Sidak method) were applied to our data set (Sigmaplot 12, Systat Software, Inc.)) except for sediment traps data for which only two replicates were done. The overall significance level was chosen as $p<0.05$.

\section{RESULTS}

\section{Nutrient Concentrations and Uptake}

At the beginning of the sampling period, phosphate concentrations were lower in the $+\mathrm{Si}$ mesocosms than in the $-\mathrm{Si}$ mesocosms $(0.02 \pm 0.02 \mu \mathrm{M}$ vs. $0.06 \pm 0.03 \mu \mathrm{M})$. Phosphate concentrations in the mesocosms increased during the first 10 days of the experiment. After Day 10, however, concentrations of phosphate decreased in all but the $+\mathrm{Si}+\mathrm{Cops}$ mesocosms (Figure 3A). The total net phosphate uptake during the sampling period (Figure 4A, Table 1) in the $-\mathrm{Si}$-Cops mesocosms $(0.11 \pm 0.02 \mu \mathrm{M})$ was lower than in the other three treatments $(+\mathrm{Si}-$ Cops: $0.17 \pm 0.04 \mu \mathrm{M}$; $+\mathrm{Si}+$ Cops: $0.16 \pm$ $0.04 \mu \mathrm{M} ;-\mathrm{Si}+$ Cops: $0.18 \pm 0.01 \mu \mathrm{M})$.
Concentrations of silicic acid $(\mathrm{dSi})$ in the $-\mathrm{Si}$ treatments remained close to zero throughout the experiment (Figure 3B), suggesting no measureable net $\mathrm{dSi}$ uptake in these mesocosms. In the $+\mathrm{Si}$ mesocosms, there was no dSi uptake between Days 6 and 10, with net dSi uptake between Day 1 and 6 and between Day 10 and 16 (Figure 4C). The total net $\mathrm{dSi}$ utilization in the mesocosms during the sampling period was $1.4 \pm 1.0 \mu \mathrm{M}(+\mathrm{Si}$ -Cops), $2.5 \pm 0.9 \mu \mathrm{M}$ ( $+\mathrm{Si}+\mathrm{Cops}), 0.0 \pm 0.1 \mu \mathrm{M}$ (-Si -Cops), and $-0.1 \pm 0.1 \mu \mathrm{M}$ ( $-\mathrm{Si}+$ Cops) (Table 1).

Continuously increasing cumulative net utilization of DIN in the $+\mathrm{Si}$ mesocosms resulted in lower concentrations compared to $-\mathrm{Si}$ mesocosms (Figures $3 \mathrm{~F}, 4 \mathrm{E}$, Table 1). In addition to the daily external input of nitrate of $0.22 \mu \mathrm{M}$, we observed DIN production likely caused by ammonium regeneration within the mesocosms. This was evident from the mid-experiment peak in ammonium concentrations in all mesocosms (Figure 3E). Following Day 10, however, ammonium concentrations decreased, except in +Si +Cops, were the decrease started at Day 13, suggesting that uptake exceeded regeneration in all mesocosms in the final days of the experiment. During the same period, nitrate, nitrite and overall DIN concentrations declined (Figures 3C,D), suggesting increased rates of DIN uptake rather than a decrease in the rates of ammonium regeneration (n.b. over the 17 day duration of the experiment, we would not expect to see notable amounts of nitrate being regenerated).

In the $+\mathrm{Si}$ mesocosms, net removal rates of DIN were, on average, 2-3 times faster than net removal rates of dSi (Table 1). Since dSi removal rates were undetectable in the -Si mesocosms, we could not calculate a net uptake ratio of DIN to dSi for these mesocosms. DIN to phosphate uptake ratios remained reasonably close to Redfield values of 16:1 in most of the mesocosms (Table 1).

\section{Standing Stocks and Phytoplankton Composition}

Integrated standing stocks of POC (upper $4.5 \mathrm{~m}$ ) decreased during the first days of the experiments and stabilized after Day 3 for +Cops mesocosms and after Day 6 for -Cops mesocosms (Figure 5A). The mean POC concentrations over the experimental period were $18.5 \pm 6.4 \mu \mathrm{mol} \mathrm{POC} \mathrm{L}^{-1}$ in the $+\mathrm{Si}$ - Cops, $24.7 \pm 7.7 \mu \mathrm{mol}$ POC $\mathrm{L}^{-1}$ for the $+\mathrm{Si}+$ Cops, $14.4 \pm$ $4.9 \mu \mathrm{mol} \mathrm{POC} \mathrm{L}^{-1}$ for the $-\mathrm{Si}-$ Cops and $21.0 \pm 4.1 \mu \mathrm{mol}$ POC $\mathrm{L}^{-1}$ for the $-\mathrm{Si}+$ Cops treatments, with values ranging from 10 to $37 \mu$ mol POC $L^{-1}$. Average POC concentrations were similar to those measured in the lagoon at the end of

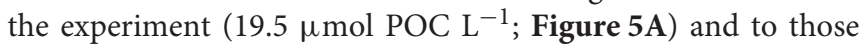
obtain at similar nutrient additions in Børsheim et al. (2005). Standing stocks of POC in the upper $4.5 \mathrm{~m}$ of the mesocosms differed more between treatments than between the replicates for each individual treatments or for each replicate over time (two way ANOVA $\alpha=0.01 ; p<0.001)$. POC standing stocks were higher in $+\mathrm{Si}$ mesocosms than in the other treatments at the beginning of the sampling period. Differences in POC standing stocks decreased over time. POC standing stocks were similar for + Cops and -Cops treatments until Day 3, but started to differ 

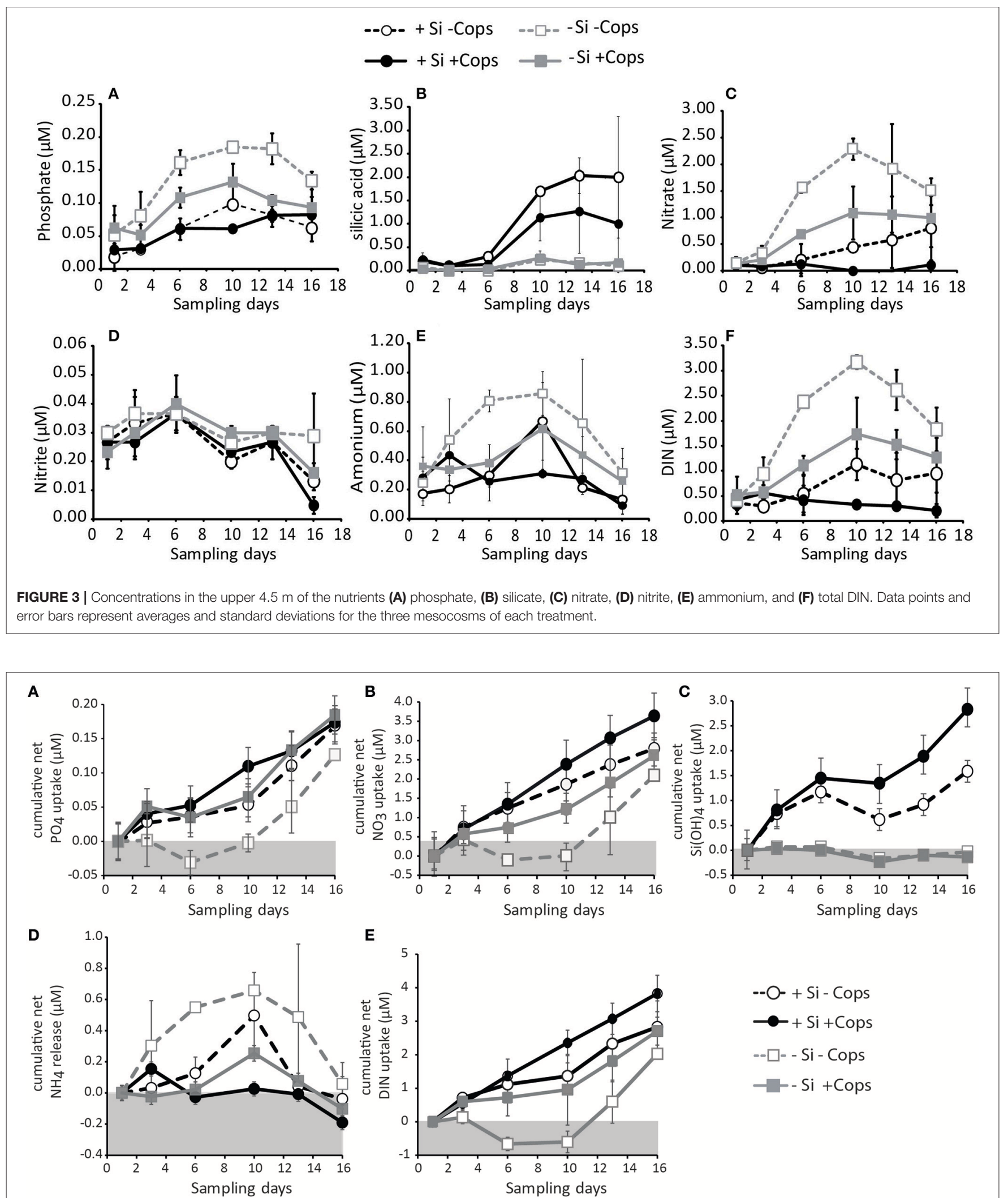

FIGURE 4 | Cumulative net uptake in the different mesocosm treatments of (A) phosphate, (B) nitrate, (C) silicate, and (E) total DIN. (D) show the cumulative net regeneration of ammonium. Data points and error bars represent averages and standard deviations for the three mesocosms of each treatment. 
TABLE 1 | Total net nutrient removal during the experiment, ratios between removal, and average number of species during the duration of the experiment.

\begin{tabular}{|c|c|c|c|c|c|c|c|c|}
\hline \multirow[t]{2}{*}{ Mesocosms } & \multicolumn{3}{|c|}{ Total net removal } & \multicolumn{2}{|c|}{ Ratios of total net removal } & \multicolumn{3}{|c|}{ Average number of species } \\
\hline & PO4 & DIN & $\mathrm{Si}(\mathrm{OH}) 4$ & DIN/Si & DIN/P & total & Diatoms & Dinoflagellates \\
\hline$+\mathrm{Si}-\mathrm{Cops}$ & 0,17 & 2,8 & 1,4 & 2,0 & 16,6 & 13 & 4 & 8 \\
\hline$+\mathrm{Si}+$ Cops & 0,16 & 3,8 & 2,5 & 1,5 & 23,9 & 19 & 4 & 12 \\
\hline -Si-Cops & 0,11 & 2,0 & 0 & - & 18,5 & 11 & 2 & 8 \\
\hline$-\mathrm{Si}+\mathrm{Cops}$ & 0,18 & 2,7 & $-0,1$ & - & 15,1 & 16 & 2 & 12 \\
\hline
\end{tabular}

after Day 6, with more POC present in the +Cops mesocosms. Over the whole sampling period, POC concentrations were significantly higher in the six mesocosms that had received a supplement of copepods compared to those where copepods had been removed (Three way ANOVA; $\mathrm{p}<0.001$ ). We also observed significantly higher POC concentrations in $+\mathrm{Si}-$ Cops compared to $-\mathrm{Si}-\mathrm{Cops}$ and in $+\mathrm{Si}+$ Cops compared to $-\mathrm{Si}+$ Cops (Three way ANOVA; $p=0.006$ ).

On the last sampling day (Day 16), the $+\mathrm{Si}+$ Cops mesocosms reached an average standing stock of POC of $25.3 \pm 0.9 \mu \mathrm{mol}$ POC $\mathrm{L}^{-1}$ and the $-\mathrm{Si}+$ Cops mesocosms an average of $23.6 \pm$ $2.4 \mu \mathrm{mol}$ POC L ${ }^{-1}$ compared to $17.6 \pm 2.6 \mu \mathrm{mol} \mathrm{POC} \mathrm{L}^{-1}$ and $15.6 \pm 0.7 \mu \mathrm{mol}$ POC $\mathrm{L}^{-1}$ in the $+\mathrm{Si}+$ Cops and $-\mathrm{Si}-$ Cops mesocosms, respectively.

Concentrations of total PON were also relatively stable during the experiment with significant differences between +Cops and -Cops mesocosms. However, unlike POC standing stocks, differences between $+\mathrm{Si}+$ Cops and $-\mathrm{Si}+$ Cops or $+\mathrm{Si}-\mathrm{Cops}$ and $-\mathrm{Si}$-Cops treatments were not significant (Figure 5B). C to $\mathrm{N}$ ratios $(\mathrm{C} / \mathrm{N})$ of the organic matter in the upper $4.5 \mathrm{~m}$ of the + Si mesocosms decreased from $6.7 \pm 0.8 \mathrm{~mol} \mathrm{~mol}^{-1}$ on Day 1 to $4.4 \pm 0.5 \mathrm{~mol} \mathrm{~mol}^{-1}$ on Day 6 and remained close to that for the rest of the experiment. The $\mathrm{C} / \mathrm{N}$ of the $-\mathrm{Si}$ mesocosms averaged $4.4 \pm 0.3 \mathrm{~mol} \mathrm{~mol}^{-1}$ during the experiment. The $\mathrm{C} / \mathrm{N}$ ratios of the standing stocks were very similar between treatments with an average for the entire experiment of $4.7 \pm 0.8 \mathrm{~mol} \mathrm{~mol}^{-1}$ (Figure 5C).

Concentrations of $\mathrm{Chl}$ a ranged from 0.5 to a maximum of $4.7 \mu \mathrm{g} \mathrm{L}^{-1}$ (Figure 5D). Chl a concentrations were generally within the range for non-bloom conditions, in accordance with the nutrient addition (Børsheim et al., 2005). Standing stocks of $\mathrm{Chl}$ a decreased rapidly in the + Si mesocosms, from $3.0 \pm 0.5$ and $4.2 \pm 0.4 \mu \mathrm{g} / \mathrm{L}$ on Day 1 for the +Cops and -Cops respectively, to $0.6 \pm 0.2$ and $0.7 \pm 0.2 \mu \mathrm{g} / \mathrm{L}$ on Day 6. After Day 6, Chl a increased until the end of the experiment to reach $2.3 \pm 0.4 \mu \mathrm{g} / \mathrm{L}$ in $+\mathrm{Si}+$ Cops and $1.1 \pm 0.6 \mu \mathrm{g} / \mathrm{L}$ in the $+\mathrm{Si}-$ Cops. Except for the first day of the sampling period, Chl a concentrations were higher in the +Cops mesocosms (three way ANOVA; $p<$ 0.001; Figure 5D). The $-\mathrm{Si}-$ Cops mesocosms also experienced a decrease from Day 1 to Day $6(1.9 \pm 0.2 \mu \mathrm{g} / \mathrm{L}$ to $0.5 \pm 0.1$ $\mu \mathrm{g} / \mathrm{L})$, before increasing to $0.9 \pm 0.4 \mu \mathrm{g} / \mathrm{L}$ at the end. The $-\mathrm{Si}$ +Cops mesocosms Chl a concentrations was less variable. Chl a concentrations slightly decreased from $2.2 \mu \mathrm{g} / \mathrm{L}$ on Day 1 to $1.4 \pm 0.4 \mu \mathrm{g} / \mathrm{L}$ at the end. The final average concentrations of $\mathrm{Chl}$ a in the $-\mathrm{Si}+$ Cops mesocosms were lower than those in the $+\mathrm{Si}+$ Cops $\left(1.4 \pm 0.4 \mu \mathrm{g} \mathrm{L}^{-1}\right.$ vs. $2.3 \pm 0.4 \mu \mathrm{g} / \mathrm{L}$, respectively, on
Day 16), but they were still $\sim 30 \%$ greater than the average final concentrations in the $+\mathrm{Si}-\mathrm{Cops}$ and $-\mathrm{Si}-\mathrm{Cops}(1.1 \pm 0.6$ and $0.9 \pm 0.4 \mu \mathrm{g} \mathrm{L}^{-1}$, respectively).

Integrated concentrations of $\mathrm{bSiO}_{2}$ in the upper $4.5 \mathrm{~m}$ of the - Si mesocosms, decreased to 0 and $0.1 \mu \mathrm{mol} / \mathrm{L}$ for - Cops and +Cops at Day 6 respectively. At the beginning of the sampling period, $\mathrm{bSiO}_{2}$ concentrations were $0.8 \pm 0.1 \mu \mathrm{mol} / \mathrm{L}$ and $0.7 \pm$ $0.1 \mu \mathrm{mol} / \mathrm{L}$ for the - Cops and + Cops respectively. In the $+\mathrm{Si}$ mesocosms, $\mathrm{bSiO}_{2}$ concentrations generally increased from Day 1 to Day 3 and then declined until Day 10 before increasing again until the end of the experiment (Figure 5E). At the end of the experiment, the $\mathrm{bSiO}_{2}$ integrated concentrations in the upper $4.5 \mathrm{~m}$ of the $+\mathrm{Si}+$ Cops mesocosms, averaged $1.6 \pm 0.6 \mu \mathrm{mol}$ $\mathrm{L}^{-1}$, which was roughly 3 -fold higher than that measured in the $+\mathrm{Si}$-Cops mesocosms $\left(0.5 \pm 0.6 \mu \mathrm{mol} \mathrm{L}^{-1}\right)$. The molar Si to POC ratios $(\mathrm{Si} / \mathrm{C})$ of standing stocks mirrored the changes in $\mathrm{bSiO}_{2}$ concentrations rather than reflecting overall patterns in the POC standing stocks (Figure 5F). Outside the mesocosms, $\mathrm{Si} / \mathrm{C}$ ratios were around 0.015 , which is similar to the lowest ratios reported for North Atlantic Waters (Ragueneau et al., 2002). The + Si mesocosms had $\mathrm{Si} / \mathrm{C}$ ratios of $0.04-0.10$, similar to global ocean average (0.04-0.25, Ragueneau et al., 2002). The Si/N ratios in the nutrient stocks of + Si treatments were higher than 1 , the average $\mathrm{Si} / \mathrm{N}$ utilization in the $+\mathrm{Si}$ mesocosms was around 1 with fluctuations from 0.6 and 2.1 .

POC standing stocks and $\mathrm{Chl}$ a concentrations were both high at the beginning of the experiments especially in the $+\mathrm{Si}$ mesocosms. Chl a estimated from CTD measurements 2 days before the beginning of the sampling period gave an average value of $2 \mathrm{mg} / \mathrm{L}$. The daily uptake rate estimated from the total nutrient additions were also lower than the first uptake calculated during the experiment $(0.2$ vs. $0.3 \mu \mathrm{M}$ /days for nitrate, $0.004 \mu \mathrm{M} /$ days vs. $0.02 \mu \mathrm{M} /$ days for phosphate and 0.3 vs. 0.3 $\mu \mathrm{M}$ /days for silicate), suggesting that no phytoplankton bloom had developed before the sampling period. Throughout the entire experiment, and in all treatments, $30-50 \%$ of the total biomass was in the $2.7-20 \mu \mathrm{m}$ size fractions, while the other four sizefractions $(0.7-2.7 \mu \mathrm{m}, 20-44 \mu \mathrm{m}, 44-100 \mu \mathrm{m}$, and $>100 \mu \mathrm{m})$ each had between 10 and $20 \%$ of the total biomass.

Taxonomic analysis confirmed that differing nutrient additions induced changes in phytoplankton population, with diatoms and flagellates dominating the $+\mathrm{Si}$ treatments, and flagellates alone dominating the $-\mathrm{Si}$ treatments (Figure 6). We identified up to 43 phytoplankton species in the $+\mathrm{Si}+$ Cops mesocosms with an average of 19 over the entire sampling period (Table 1). By contrast, a maximum of 23 species were 


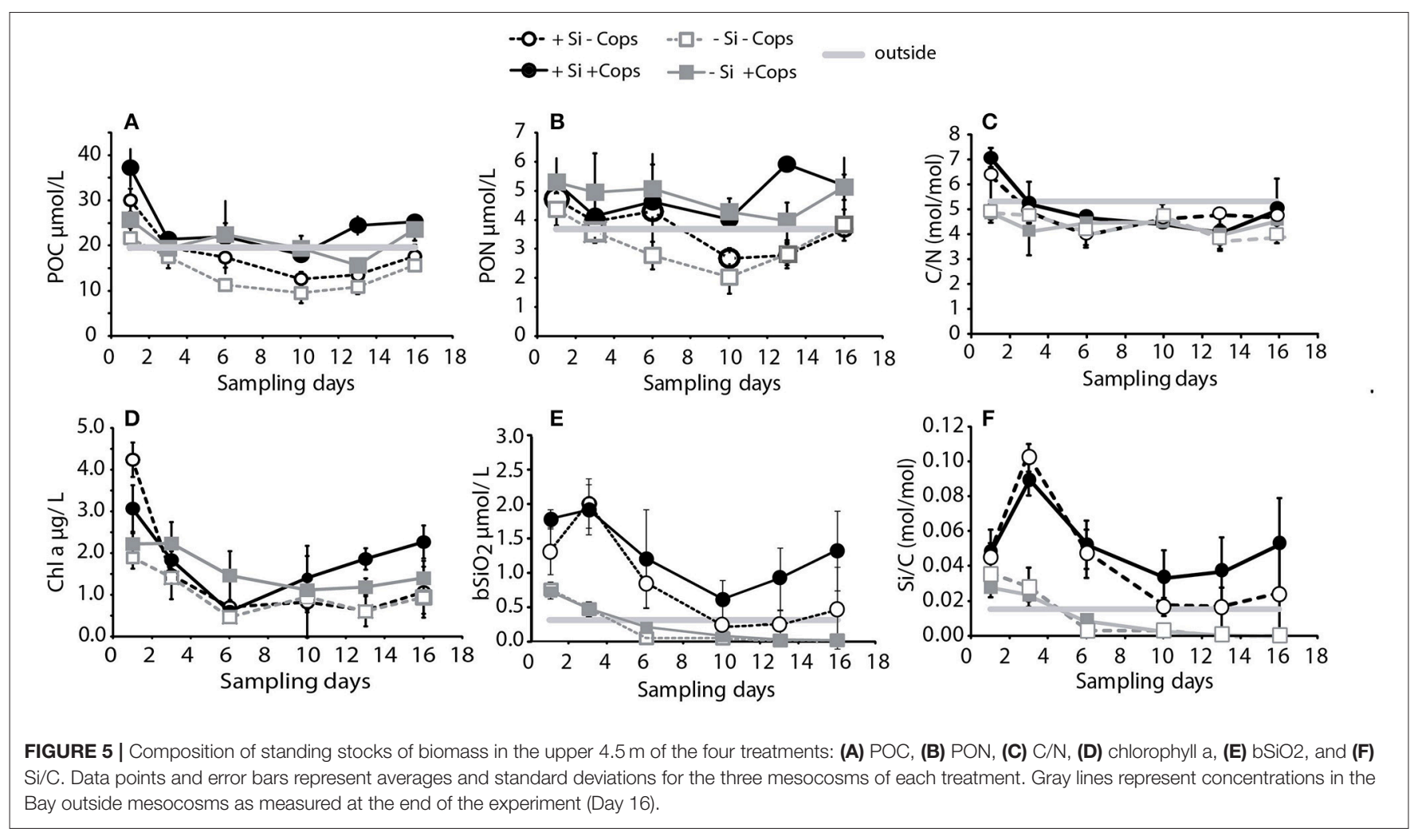

found in the $+\mathrm{Si}-\mathrm{Cops}$, with an average of 13. For the $-\mathrm{Si}$ mesocosms, the maximum number of species in + Cops and -Cops treatments was 24 and 17, respectively, with an average total amount of species of 16 and 11 for $-\mathrm{Si}+$ Cops and $-\mathrm{Si}$ -Cops treatments, respectively. In the $+\mathrm{Si}+$ Cops treatments, diatom concentrations decreased from Day 3 to Day 10, after which their abundance increased (Figure 6). At Day 13, diatoms concentrations were much lower in the $+\mathrm{Si}$ mesocosms. This result was not mirrored by standing stock measurement of $\mathrm{bSiO}_{2}$ concentrations or by total cell concentrations according to cytometry. This sudden change of diatom concentrations may therefore potentially be due to analytical problems with phytoplankton enumeration at this sampling day.

In the + Si treatments, $97 \%$ of the diatom populations were constituted by small species (cell volume $<2500 \mu \mathrm{m}^{3}$ ) until Day 6. Skeletonema marinoii (diameter $\sim 10 \mu \mathrm{m}$ ) dominate all treatments until Day 3 and disappeared from -Si mesocosms thereafter. From Day 13 the diatom population of the $+\mathrm{Si}$ -Cops treatments switched from small $S$. marinoii to medium sized-diatoms, with Cylindrotheca closterium (50 to $125 \mu \mathrm{m}$ length) forming most of the population in $+\mathrm{Si}-$ Cops while Leptocylindrus danicus constituted more than $90 \%$ of the $+\mathrm{Si}$ + Cops diatom population. The + Si treatments also developed a large population of dinoflagellates, with the Gymnodinium sp. dominating the dinoflagellates population, except for the $+\mathrm{Si}$ -Cops after Day 6 when Scripsiella contribute for more than $50 \%$ to the dinoflagellates population.

Dinoflagellates dominated the $-\mathrm{Si}$ treatments from Day 3 until the end of the experiments, with Gymnodinium sp. and
Scrippsiella (trochoida and sweenea) making up 60 to $95 \%$ of the total dinoflagellates community in terms of cell abundance. Gymnodinium sp. dominate the community before Day 6 and Scrippsiella after.

\section{Sinking Fluxes}

Gel traps showed that sinking particles mostly consisted of fecal pellets and large aggregates such as marine snow. During the first trap deployment the $+\mathrm{Si}$-Cops mesocosms particle fluxes were characterized by a higher contribution of marine snow and fewer fecal pellets than the $+\mathrm{Si}+$ Cops treatments. The flux composition between these two treatments became more similar toward the end of the study. At the end of the study, particle fluxes in the + Si treatments where characterized by more marine snow aggregates than the $-\mathrm{Si}$ that had a much higher contribution by fecal pellets (Figure 7). Sinking fluxes of POC, $\mathrm{PON}$, and $\mathrm{bSiO}_{2}$ decreased over time (Figure 7), not mirroring standing stocks in the upper $4.5 \mathrm{~m}$ of the mesocosms (Figure 5). The total POC exported during the experiment was $1.47 \pm 0.30 \mathrm{~g}$

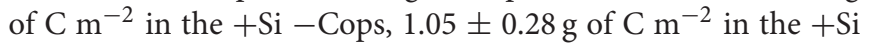
+ Cops, $0.78 \pm 0.10 \mathrm{~g}$ of $\mathrm{C} \mathrm{m}^{-2}$ in the $-\mathrm{Si}-$ Cops and $0.86 \pm$ $0.24 \mathrm{~g}$ of $\mathrm{C} \mathrm{m}^{-2}$ in the $-\mathrm{Si}+\mathrm{Cops}$ (Figure 8). The $\mathrm{C} / \mathrm{N}$ ratio of the material sinking into sediment traps was higher than the $\mathrm{C} / \mathrm{N}$ ratios found in the suspended particles with more variability between traps than between treatments $(\mathrm{C} / \mathrm{N}$ in standing stocks $=4.5 \pm 0.6 ; \mathrm{C} / \mathrm{N}$ in sinking particles $=7.6 \pm 2.0)$. The difference between $\mathrm{C} / \mathrm{N}$ in sediment traps and standing stocks was very pronounced in the $-\mathrm{Si}$-Cops at the end of the experiment, when flux $\mathrm{C} / \mathrm{N}$ ratios value reached an average of $10.6 \pm 5$. 


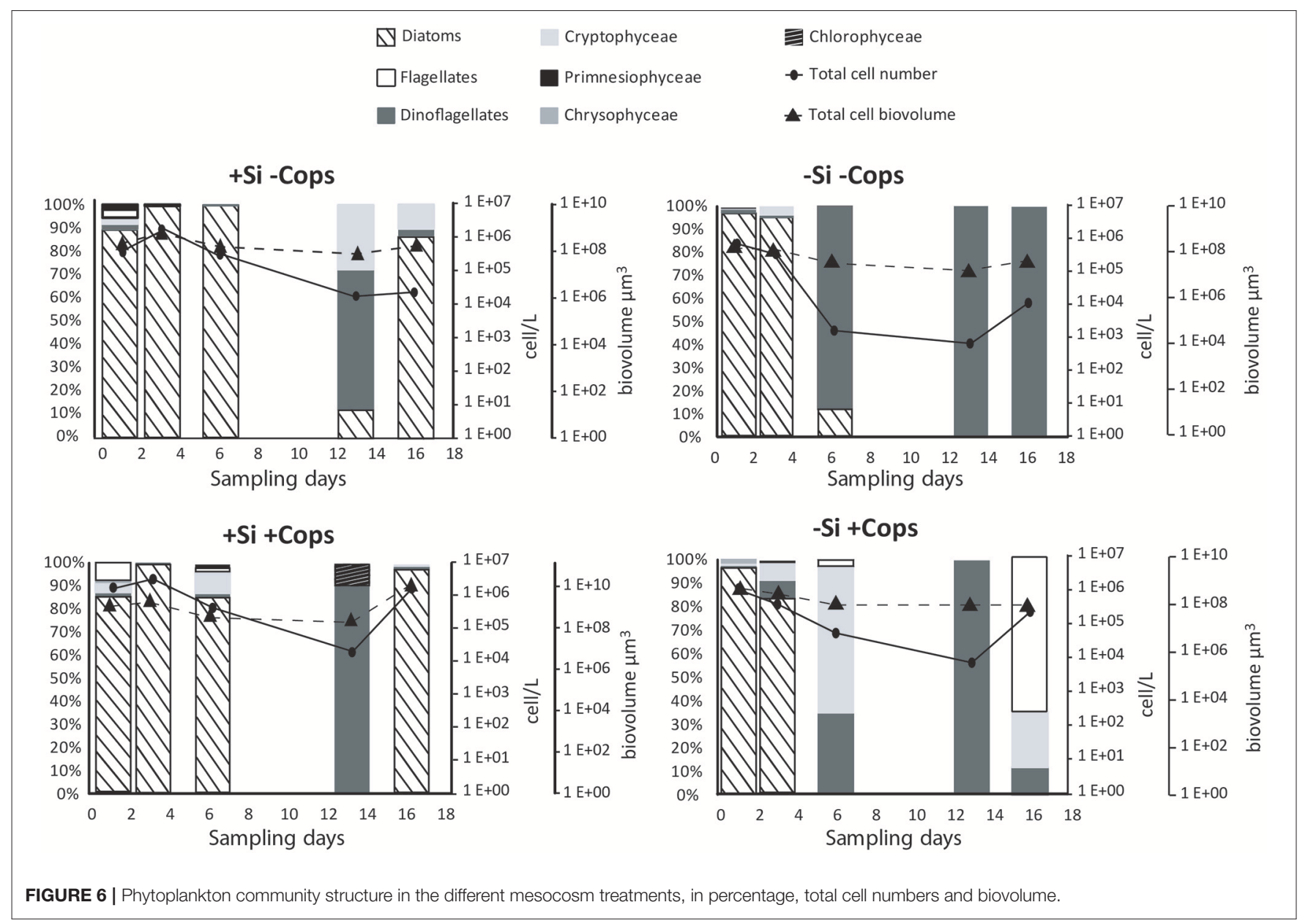

The ratios of $\mathrm{bSiO}_{2}$ to $\mathrm{POC}$ of sinking particles $(\mathrm{Si} / \mathrm{C})$ were twice those measured in suspended particles (Figure 8). This difference increased with elevated copepod abudances. Despite the lack of measurable $\mathrm{bSiO}_{2}$ in the suspended particles after day 6 , $\mathrm{Si} / \mathrm{C}$ ratios for the sinking material were still 0.02 in the $-\mathrm{Si}$ mesocosms and some diatoms were observed in the sediment traps. The POC fluxes were positively correlated to the $\mathrm{Si} / \mathrm{C}$ ratios of the standing stocks (Figure 9). Only the sinking material of the traps set up at day 8 and 16 were analyzed for the phytoplankton taxonomy. Small diatoms formed 96 to $100 \%$ of the diatom fluxes collected in all traps except at the end of the experiment. In the $+\mathrm{Si}-$ Cops the medium sized $(<125 \mu \mathrm{m})$ Cylindrotheca closterium formed $60 \%$ of the diatom cell numbers found in the sediment traps. The contribution of Proboscia alata increased in the $+\mathrm{Si}+$ Cops to achieve half of the sinking at the end.

\section{DISCUSSION}

Diatoms with their ballasted frustule (Armstrong et al., 2002; François et al., 2002) have long been recognized to be efficient for downward transport of matter (Smetacek, 1985; Nelson et al., 1995; Sarmiento et al., 2004). Recent studies are challenging this belief highlighting rather potential links between export and the structure of the whole plankton community (Henson et al., 2012; Lima et al., 2014; Guidi et al., 2016). Additionally a combination of poorly understood processes, such as gravitational settling as aggregates or fecal pellets, physical transport of particulate and dissolved organic matter, or zooplankton disaggregation or migration may also contribute substantially to downward transport of matter (Sanders et al., 2014; Turner, 2015; Siegel et al., 2016).

\section{Impact of Phytoplankton Community Structure}

Daily addition of small amount of dSi triggered the growth of diatoms in the $+\mathrm{Si}$ mesocosms and globally increased POC fluxes (Figure 8), with however, 50 to 100 -fold less carbon exported per unit $\mathrm{d} S \mathrm{Si}$ in our non-blooming situation compared to similar bloom simulating experiment (Wassmann et al., 1996). All treatments showed strong positive correlations between the POC fluxes and the Si to POC ratios of suspended material in the upper $5 \mathrm{~m}$ of the mesocoms (Figure 9) suggesting that the magnitude of POC export was first driven by the presence of diatoms. This is supported by the high POC flux in the $+\mathrm{Si}-$ Cops at Day 6 (Figure 7) and by the high export efficiency in the $+\mathrm{Si}$-Cops mesocosms, in terms 


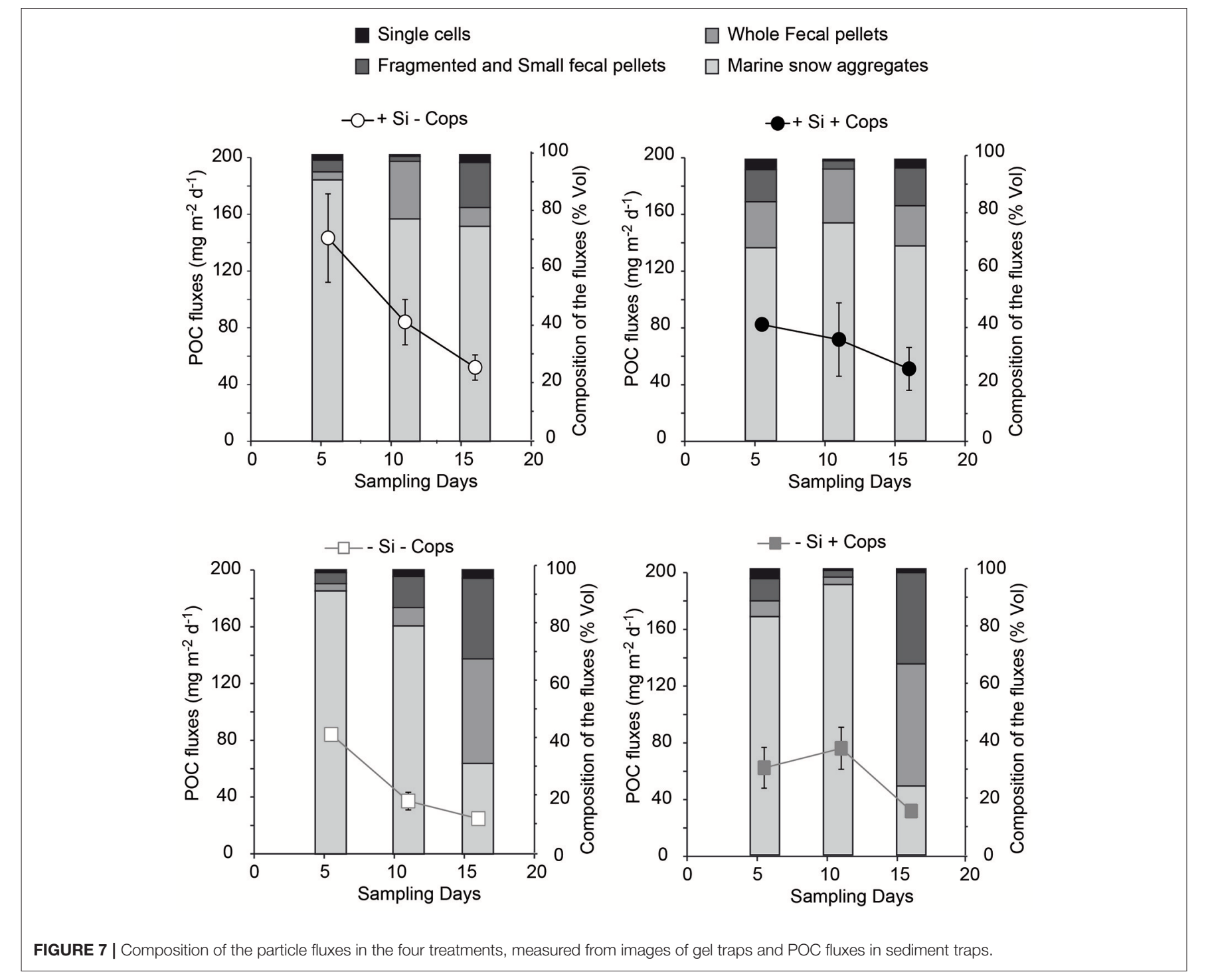

of the amount of POC produced reaching the sediment traps (Figure 10). Globally, POC flux intensities follow the aggregate contribution to the flux, with downward trend when the aggregate contribution to fluxes decrease (Figure 7). On the $+\mathrm{Si}$ mesocosms the aggregate contribution was slightly lower than the average aggregate contributions in the flux of the $-\mathrm{Si}$ mesocosms at Day 6 and 11, when Gymnodinium sp. dominate the phytoplankton population. However, when aggregate contribution to the flux is similarly high such as seen at Day 6 for $+\mathrm{Si}$-Cops and $-\mathrm{Si}$-Cops, the flux is almost twice as high in the diatom dominated treatment compared to $-\mathrm{Si}$ treatments. Aggregation capacity is not restricted to diatom species (Cataletto et al., 1996), but diatom aggregates transport more carbon than non-ballasted aggregates due to higher density and sinking rates (Long et al., 2015). However, even for non-diatom species, decreased aggregation involved lower fluxes as seen at the end of the experiment in -Si mesocosms in association to the growth of Scrippsiela sp..

Aggregate contribution to the fluxes stay around $82 \%$ in the $+\mathrm{Si}$-Cops, where the aggregating species Skeletonema marinoii, and Pseudonitzschia sp and Cylindroteca closterium prevailed (Cataletto et al., 1996). In the +Si +Cops the aggregating $S$. marinoii constituted most of the diatom population at the beginning of the sampling period. The non-aggregating Leptocylindrus danicus (Cataletto et al., 1996) that dominate diatom population at the end were not visible in the sediment traps where the aggregates still formed $70 \%$ of the particles collected. Instead the large non-aggregating Proboscia alata and the small aggregating S. marinoii were majoritary in the sediment traps confirming that size may be also an important factor, together with ballast and aggregation capacity for an efficient carbon export. 

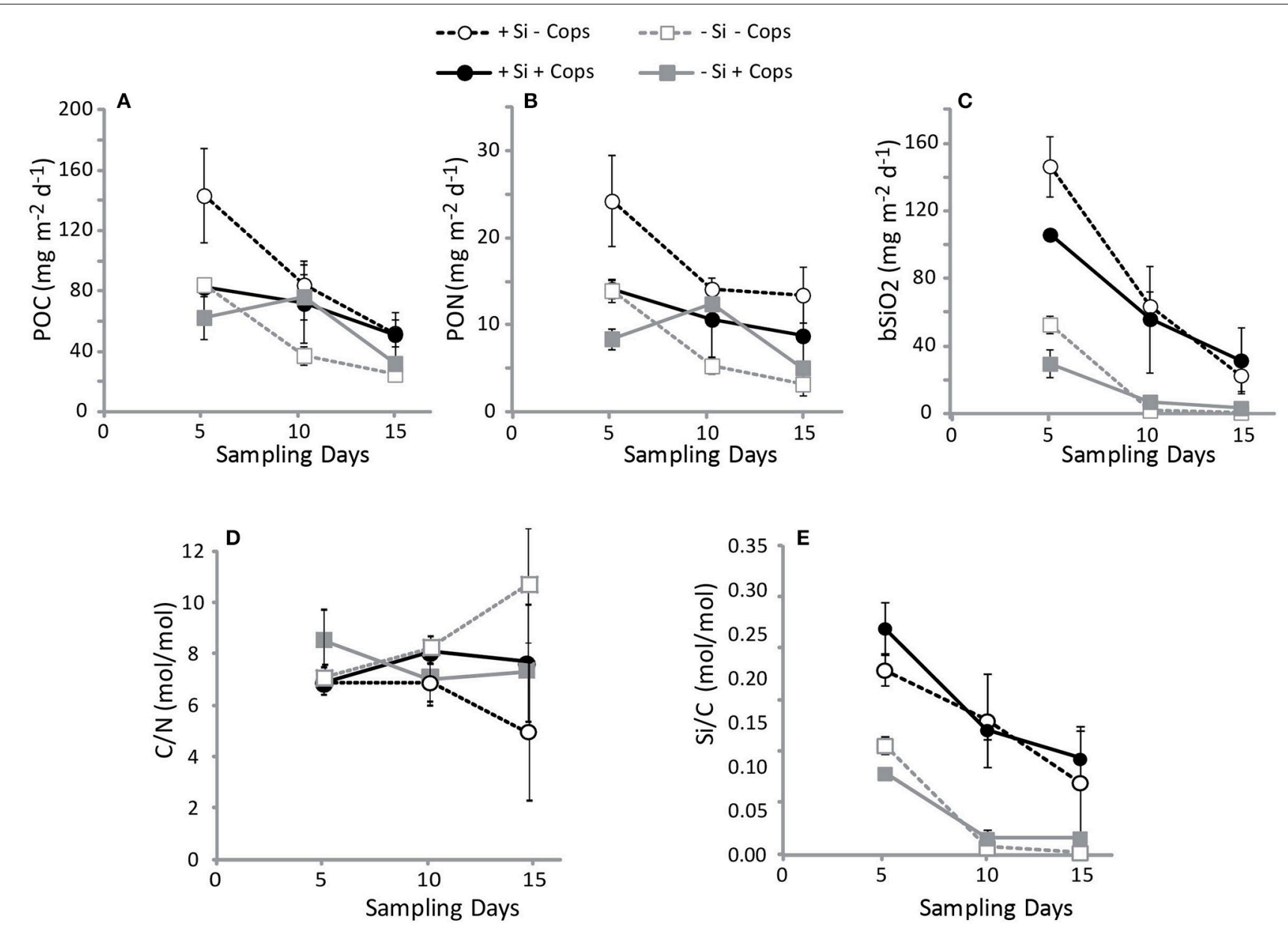

FIGURE 8 | Flux of material into the sediment traps and its elemental composition averaged for each mesocosm treatment. (A) POC, (B) PON, (C) bSiO 2 , (D) the $\mathrm{C} / \mathrm{N}$ of the sinking flux, and (E) the Si/C of the sinking flux.

\section{The Importance of Zooplankton Abundance to POC Flux}

The global role of zooplankton for POC export is difficult to quantify since zooplankton indirectly influence export by changing the structure of the phytoplankton community, from small to larger species as seen in the previous paragraph and in other study (Quéguiner, 2013). Moreover, zooplankton activity may both (1) increase POC fluxes by converting slow-sinking single cells into fast-sinking fecal pellets and (2) reduce the flux by fragmenting large aggregates into small particle with slow sinking velocities and high degradation in the surface ocean (Iversen and Poulsen, 2007; Giering et al., 2014; Sanders et al., 2014). In our mesocosm study, higher copepod concentrations resulted in higher standing stock of phytoplankton (Figure 4) and in higher phytoplankton diversity (Table 1). The flagellate diversity appeared to be mainly driven by the copepod presence. Diatom diversity was more influenced by the silicic acid addition but the dominant species change depending on the copepod abundances (Table 1). Higher phosphate and nitrate uptake in the +Cops treatments compared to the -Cops treatments (Figure 4), suggest that the phytoplankton community benefitted from the presence of mesozooplankton. Such a counter-intuitive influence of meso-zooplankton addition on phytoplankton growth has already been observed in other studies (Sommer et al., 2001, 2004, 2005). The silicate uptake also increased with copepods addition (Figure 4). This could be explained by the change of diatoms community toward more silicified species (Assmy et al., 2013; Quéguiner, 2013), or by the increase of diatom silicification in the presence of grazers (Pondaven et al., 2007). Grazers feeding activity may also increase the remineralization of the dead diatom frustules (Schultes et al., 2010). Such an effect would benefit diatom growth but couldn't be seen in our study because we only measured the net uptake. Moreover, the trophic connections are much more complex than only copepods and prey. Additionally, trophic cascades can explain the increased phytoplankton biomass in the +Cops mesocosms (Gismervik et al., 2002; Sommer et al., 2004; Stibor et al., 2004). Copepods may partially feed on microzooplankton. The grazing pressure of micro-zooplankton on phytoplankton would then be reduced as observed in previous mesocosm experiments (Gismervik 


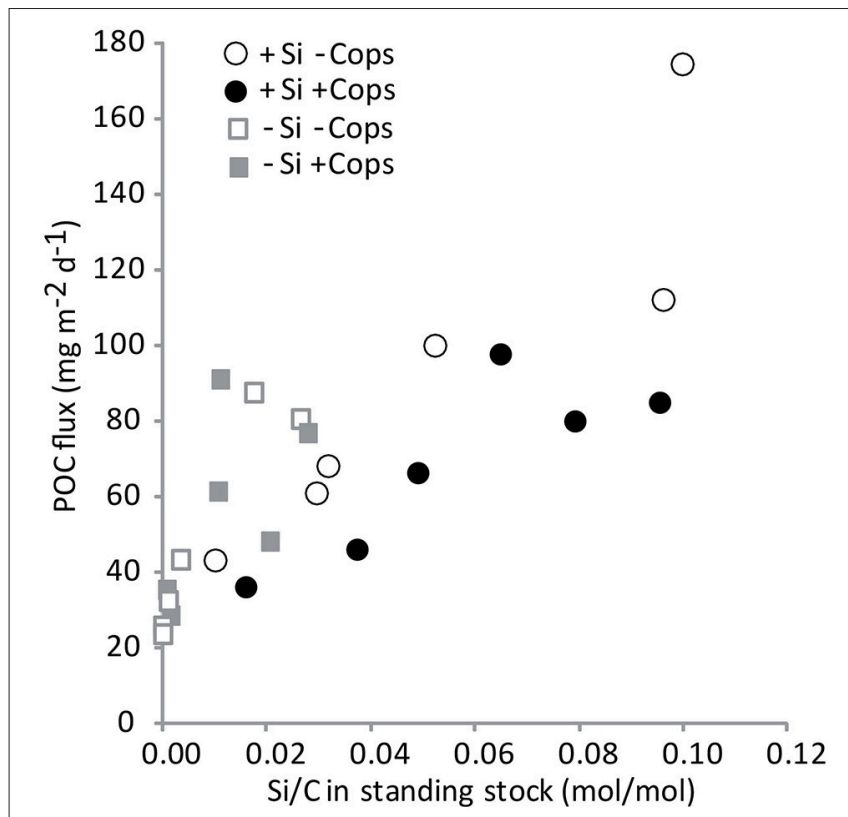

FIGURE 9 | POC fluxes versus $\mathrm{Si} / \mathrm{C}$ ratios in the standing stocks in the upper $4.5 \mathrm{~m}$.

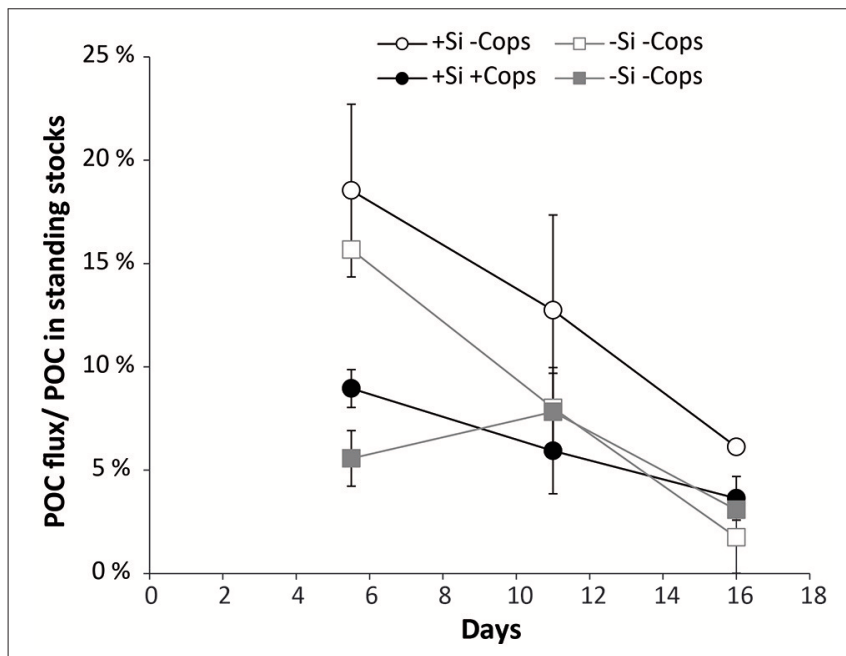

FIGURE 10 | Export efficiency: proportion of the POC produced in the surface layer, collected in the sediment traps versus time for the four treatments $+\mathrm{Si}$ -Cops, +Si +Cops, - Si -Cops and -Si -Cops.

et al., 2002; Stibor et al., 2004). In this case, an increase of the copepods abundance mean a decrease of the grazing pressure on phytoplankton, and an increase of the phytoplankton net growth.

In terms of export fluxes, we observed that elevated copepod concentrations decreased the POC flux in the +Si while the opposite was observed for $-\mathrm{Si}$ treatments (Figure 8). The highest difference can be seen for + Si at Day 6 where copepods strongly impact the flux composition decreasing aggregate contribution to the flux (from 92 to $68 \%$ for -Cops and +Cops, respectively, Figure 7). This could have resulted from two mechanisms, a mechanic breakage of the aggregates (Alldredge et al., 1990; Dilling and Alldredge, 2000) or by changing diatom community because diatoms are not equal in terms of aggregation capacity (Cataletto et al., 1996). However until Day 6 the aggregating species Skeletonema marinoii dominate the two treatments suggesting at this time that physical breakage of aggregates by zooplankton feeding and swimming activities must have prevailed. But copepods activities also influenced the diatom community: in the $+\mathrm{Si}+\mathrm{Cops}$, the biovolume of the diatom population increased toward the end (Figure 6) with larger species progressively dominating the diatom community (from S. marinoii to L. danicus). We also observed an impact of copepod activity on the species composition of the sinking material. Similarly to observations done in the Kerguelen area, preferential feeding by copepods resulted in an increased proportion of heavily silicified diatoms in the sinking flux (Quéguiner, 2013) even when they are not so well represented in the surface water populations. Diatom composition of the export fluxes in $+\mathrm{Si}$ -Cops reflected that of the suspended diatom community, but most of the material recovered in the $+\mathrm{Si}+$ Cops traps were constituted by the large and heavily silicified Proboscia alata and aggregates of $S$. marinoii.

Reversely in the $-\mathrm{Si}$ mesocosms, higher copepod concentrations were associated with increased POC fluxes, with a stronger contribution of aggregates at Day 11 and of intact fecal pellets toward the end of the mesocosm study (Figure 7). While the intensity of the POC fluxes generally follow the aggregate contribution to the flux, the slight decrease of the flux intensity at the end in the $-\mathrm{Si}+$ Cops mesocosm traps confirm that fecal pellets production can compensate for the disaggregation process in a non-diatom situation.

Overall, our data suggests that zooplankton decreased the efficiency of the system to export POC in diatom dominated ecosystem (Figure 10). For dinoflagellates dominated systems, the net export is increasing due to the positive effect of copepod activity on phytoplankton growth. However, except at Day 6, the efficiency of the system in terms of how much of POC production was exported was not affected by copepod abundance (Figure 10). Instead of copepods simply ingesting and repackaging phytoplankton into fecal pellets in proportions similar to the community composition in the mixed layer, copepods actively shape the phytoplankton community structure in the surface layer and in the export fluxes by selective grazing which determines which phytoplankton species are being retained in the upper ocean, and which ones are being exported.

\section{CONCLUSIONS}

In our large scale experimental non-bloom conditions, POC fluxes were positively correlated to $\mathrm{Si} / \mathrm{C}$ in all mesocosms, highlighting the global importance of diatoms for POC export. The addition of $\mathrm{dSi}$ increased POC fluxes, confirming the results by Wassmann et al. (1996). Lightly silicified diatoms, which dominated water column in most mesocosms during our study, drive the export through aggregation when copepods concentration is decreased. With elevated copepod 
concentrations, net phytoplankton growth globally increased, probably due to trophic cascade effect. Grazing pressure also structure the phytoplankton community, with a shift from small to medium or large diatoms in the water column and in the export fluxes. Simultaneously aggregates are mechanically broken by copepod activity which is not compensated by the increase density of the diatoms escaping the grazing. These two opposite effects in diatom dominated ecosystem resulted in a net decrease of the export efficiency. Reversely by favoring phytoplankton growth and formation of fast sinking fecal pellets, copepods increase the net export by non-diatom species, but do not clearly change the export efficiency.

\section{AUTHOR CONTRIBUTIONS}

$\mathrm{BM}$ and $\mathrm{CD}$ contributed to the conception of the experiment, to find the fundings, to the acquisition, analysis, and interpretation of data and wrote the manuscript. MI and MG contributed to

\section{REFERENCES}

Alldredge, A. L., Granata, T. C., Gotschalk, C. C., and Dickey, T. D. (1990). The physical strength of marine snow and its implications for particle disaggregation in the ocean. Limnol. Oceanogr. 35, 1415-1428. doi: 10.4319/lo.1990.35.7.1415

Alvain, S., Le Quéré, C., Bopp, L., Racault, M.-F., Beaugrand, G., Dessailly, D., et al. (2013). Rapid climatic driven shifts of diatoms at high latitudes. Remote Sens. Environ. 132, 195-201. doi: 10.1016/j.rse.2013.01.014

Armstrong, R. A., Lee, C., Hedges, J. I., Honjo, S., and Wakeham, S. G. (2002). A new, mechanistic model for organic carbon fluxes in the ocean based on the quantitative association of POC with ballast minerals. Deep Sea Res. II 49, 219-236. doi: 10.1016/S0967-0645(01)00101-1

Assmy, P., Smetacek, V., Montresor, M., Klaas, C., Henjes, J., Strass, V. H., et al. (2013). Thick-shelled, grazer-protected diatoms decouple ocean carbon and silicon cycles in the iron-limited Antarctic Circumpolar Current. Proc. Natl. Acad. Sci. U.S.A. 110, 20633-20638. doi: 10.1073/pnas.1309345110

Bach, L. T., Taucher, J., Boxhammer, T., Ludwig, A., The Kristineberg, KOSMOS Consortium., Achterberg, E. P., et al. (2016). Influence of ocean acidification on a natural winter-to-summer plankton succession: first insights from a longterm mesocosm study draw attention to periods of low nutrient concentrations. PLoS ONE 11:e0159068. doi: 10.1371/journal.pone.0159068

Bopp, L. (2005). Response of diatoms distribution to global warming and potential implications: a global model study. Geophys. Res. Lett. 32:L19606. doi: 10.1029/2005GL023653

Bopp, L., Resplandy, L., Orr, J. C., Doney, S. C., Dunne, J. P., Gehlen, M., et al. (2013). Multiple stressors of ocean ecosystems in the 21st century: projections with CMIP5 models. Biogeosciences 10, 6225-6245. doi: 10.5194/bg-10-6225-2013

Børsheim, K. Y., Vadstein, O., Myklestad, S. M., Reinertsen, H., Kirkvold, S., and Olsen, Y. (2005). Photosynthetic algal production, accumulation and release of phytoplankton storage carbohydrates and bacterial production in a gradient in daily nutrient supply. J. Plankton Res. 27, 743-755. doi: 10.1093/plankt/fbi047

Boyd, P. W., and Trull, T. W. (2007). Understanding the export of biogenic particles in oceanic waters: Is there consensus? Prog. Oceanogr. 72, 276-312. doi: $10.1016 /$ j.pocean.2006.10.007

Buesseler, K. O., and Boyd, P. W. (2009). Shedding light on processes that control particle export and flux attenuation in the twilight zone of the open ocean. Limnol. Oceanogr. 54, 1210-1232. doi: 10.4319/lo.2009.54.4.1210

Cataletto, B., Feoli, E., Umani, S. F., Monti, M., and Pecchiar, I. (1996). Analyses of the relationship between mucous aggregates and phytoplankton communities in the Gulf of Trieste (Northern Adriatic Sea) by multivariate techniques. Mar. Ecol. 17, 291-307. doi: 10.1111/j.1439-0485.1996.tb00509.x the conception of the experiment, to the acquisition, analysis, and interpretation of data and writting of the manuscript. ML, RL, HS, MS, and A-JE, contributed to the conception of the experiment, to the acquisition and analysis of data and revised the manuscript. $\mathrm{BB}, \mathrm{JB}, \mathrm{RC}, \mathrm{NC}, \mathrm{AD}, \mathrm{SG}, \mathrm{MK}, \mathrm{CL}, \mathrm{AL}$, and $\mathrm{AM}$ contributed to the acquisition and analysis of data and revised the manuscript.

\section{ACKNOWLEDGMENTS}

Immeasurable thanks are owed to everyone whose technical support and advice made this experiment possible: A. Neyts, HS, RC, AL, E. Achterberg, O. Vadstein, Y. Olsen, and M. St. John. This research was supported by the European Community's 7th Framework Programme's Integrating Activity HYDRALAB IV (No. 261520) and Integrating Project EURO-BASIN (No. 264933). Thank you to the two reviewers that greatly help to improve this manuscript.

Dilling, L., and Alldredge, A. L. (2000). Fragmentation of marine snow by swimming macrozooplankton: A new process impacting carbon cycling in the sea. Deep Sea Res. Part Oceanogr. Res. Pap. 47, 1227-1245. doi: 10.1016/S0967-0637(99)00105-3

Dortch, Q., and Maske, H. (1982). Dark uptake of nitrate and nitrate reductase activity of a red-tide population off peru. Mar. Ecol. Prog. Ser. 9, 299-303. doi: 10.3354/meps009299

Engel, A., Goldthwait, S., Passow, U., and Alldredge, A. L. (2002). Temporal decoupling of carbon and nitrogen dynamics in a mesocosm diatom bloom. Limnol. Oceanogr. 47, 753-761. doi: 10.4319/lo.2002.47.3.0753

François, R., Honjo, S., Krishfield, R., and Manganini, S. (2002). Factors controlling the flux of organic carbon to the bathypelagic zone of the ocean. Glob. Biogeochem. Cycles 16, 34-1-34-20. doi: 10.1029/2001GB001722

Fujii, M., and Chai, F. (2005). Effects of biogenic silica dissolution on silicon cycling and export production. Geophys. Res. Lett. 32:L05617. doi: 10.1029/2004GL 022054

Gazeau, F., Sallon, A., Pitta, P., Tsiola, A., Maugendre, L., Giani, M., et al. (2017). Limited impact of ocean acidification on phytoplankton community structure and carbon export in an oligotrophic environment: results from two short-term mesocosm studies in the Mediterranean Sea. Estuar. Coast. Shelf Sci. 186, 72-88. doi: 10.1016/j.ecss.2016.11.016

Gehlen, M., Bopp, L., Emprin, N., Aumont, O., Heinze, C., and Ragueneau, O. (2006). Reconciling surface ocean productivity, export fluxes and sediment composition in a global biogeochemical ocean model. Biogeosci. Discuss. 3, 803-836. doi: 10.5194/bgd-3-803-2006

Giering, S. L., Sanders, R., Lampitt, R. S., Anderson, T. R., Tamburini, C., Boutrif, M., et al. (2014). Reconciliation of the carbon budget in the ocean/'s twilight zone. Nature 507, 480-483. doi: 10.1038/nature13123

Gismervik, I., Olsen, Y., and Vadstein, O. (2002). "Micro-and mesozooplankton response to enhanced nutrient input-a mesocosm study," in Sustainable Increase of Marine Harvesting: Fundamental Mechanisms and New Concepts (Dordrecht: Springer), 75-87.

Guidi, L., Chaffron, S., Bittner, L., Eveillard, D., Larhlimi, A., Roux, S., et al. (2016). Plankton networks driving carbon export in the oligotrophic ocean. Nature 532, 465-470. doi: 10.1038/nature16942

Henson, S. A., Sanders, R., and Madsen, E. (2012). Global patterns in efficiency of particulate organic carbon export and transfer to the deep ocean. Glob. Biogeochem. Cycles 26:GB1028. doi: 10.1029/2011GB004099

Henson, S. A., Yool, A., and Sanders, R. (2015). Variability in efficiency of particulate organic carbon export: a model study. Glob. Biogeochem. Cycles 29, 33-45. doi: 10.1002/2014GB004965

Honjo, S., Manganini, S. J., Krishfield, R. A., and Francois, R. (2008). Particulate organic carbon fluxes to the ocean interior and factors controlling the biological 
pump: a synthesis of global sediment trap programs since 1983. Prog. Oceanogr. 76, 217-285. doi: 10.1016/j.pocean.2007.11.003

Iversen, M., and Poulsen, L. K. (2007). Coprohexy, coprophagy, and coprochaly in the copepods Calanus helgolandicus, Pseudocalanus elongatus, and Oithona similis. Mar. Ecol. Prog. Ser. 350, 79-89. doi: 10.3354/meps07095

Kemp, A. E. S., Pearce, R. B., Grigorov, I., Rance, J., Lange, C. B., Quilty, P., et al. (2006). The production of giant marine diatoms and their export at oceanic frontal zones: implications for Si and C flux in stratified oceans. Glob. Biogeochem. Cycles 20:GB4S04. doi: 10.1029/2006GB002698

Kemp, A. E. S., and Villareal, T. A. (2013). High diatom production and export in stratified waters - A potential negative feedback to global warming. Prog. Oceanogr. 119, 4-23. doi: 10.1016/j.pocean.2013.06.004

Klaas, C., and Archer, D. E. (2002). Association of sinking organic matter with various types of mineral ballast in the deep sea: implications for the rain ratio. Glob. Biogeochem. Cycles 16, 63-1-63-14. doi: 10.1029/2001GB001765

Klaas, C., Verity, P. G., and Schultes, S. (2008). Determination of copepod grazing on natural plankton communities: correcting for trophic cascade effects. Mar. Ecol. Prog. Ser. 357, 195-206. doi: 10.3354/meps07262

Koroleff, F. (1969). Direct determination of ammonia in natural waters as indophenol blue. ICES CM 100:9.

Lalande, C., Moriceau, B., Leynaert, A., and Morata, N. (2016). Spatial and temporal variability in export fluxes of biogenic matter in Kongsfjorden. Polar Biol. 39, 1725-1738. doi: 10.1007/s00300-016-1903-4

Lam, P. J., Doney, S. C., and Bishop, J. K. B. (2011). The dynamic ocean biological pump: Insights from a global compilation of particulate organic carbon, $\mathrm{CaCO}_{3}$, and opal concentration profiles from the mesopelagic: the dynamic ocean biological pump. Glob. Biogeochem. Cycles 25:GB3009. doi: 10.1029/2010GB003868

Larsen, A., Egge, J. K., Nejstgaard, J. C., Di Capua, I., Thyrhaug, R., Bratbak, G., et al. (2015). Contrasting response to nutrient manipulation in Arctic mesocosms are reproduced by a minimum microbial food web model. Limnol. Oceanogr. 60, 360-374. doi: 10.1002/lno.10025

Lasbleiz, M., Leblanc, K., Blain, S., Ras, J., Cornet-Barthaux, V., Hélias Nunige, S., et al. (2014). Pigments, elemental composition (C, N, P, and $\mathrm{Si}$ ), and stoichiometry of particulate matter in the naturally iron fertilized region of Kerguelen in the Southern Ocean. Biogeosciences 11, 5931-5955. doi: 10.5194/bg-11-5931-2014

Lee, C., Peterson, M. L., Wakeham, S. G., Armstrong, R. A., Cochran, J. K., Miquel, J. C., et al. (2009). Particulate organic matter and ballast fluxes measured using time-series and settling velocity sediment traps in the northwestern Mediterranean Sea. Deep Sea Res. Part II Top. Stud. Oceanogr. 56, 1420-1436. doi: $10.1016 / j . d s r 2.2008 .11 .029$

Lima, I. D., Lam, P. J., and Doney, S. C. (2014). Dynamics of particulate organic carbon flux in a global ocean model. Biogeosciences 11, 1177-1198. doi: 10.5194/bg-11-1177-2014

Litchman, E., Klausmeier, C. A., and Bossard, P. (2004). Phytoplankton nutrient competition under dynamic light regimes. Limnol. Oceanogr. 49, 1457-1462. doi: 10.4319/lo.2004.49.4_part_2.1457

Long, M., Moriceau, B., Gallinari, M., Lambert, C., Huvet, A., Raffray, J., et al. (2015). Interactions between microplastics and phytoplankton aggregates : impact on their respective fates. Mar. Chem. 175, 39-46. doi: 10.1016/j.marchem.2015.04.003

Lutz, M., Dunbar, R., and Caldeira, K. (2002). Regional variability in the vertical flux of particulate organic carbon in the ocean interior: regional variability in vertical poc flux. Glob. Biogeochem. Cycles 16, 11-1-11-18. doi: 10.1029/2000GB001383

McDonnell, A. M., and Buesseler, K. O. (2010). Variability in the average sinking velocity of marine particles. Limnol. Oceanogr. 55, 2085-2096. doi: 10.4319/lo.2010.55.5.2085

Moriceau, B., Gallinari, M., Soetaert, K., and Ragueneau, O. (2007). Importance of particle formation to reconstructed water column biogenic silica fluxes. Glob. Biogeochem. Cycles 21:GB3012. doi: 10.1029/2006GB002814

Morris, P. J., Sanders, R., Turnewitsch, R., and Thomalla, S. (2007). 234Th-derived particulate organic carbon export from an island-induced phytoplankton bloom in the Southern Ocean. Crozet Nat. Iron Bloom Export Exp. 54, 2208-2232. doi: 10.1016/j.dsr2.2007.06.002

Nelson, D. M., Tréguer, P., Brzezinski, M. A., Leynaert, A., and Quéguiner, B. (1995). Production and dissolution of biogenic silica in the ocean: revised global estimates, comparison with regional data and relationship to biogenic sedimentation. Glob. Biogeochem. Cycles 9, 359-372. doi: 10.1029/95GB01070

Olsen, Y., Agustí, S., Andersen, T., Duarte, C. M., Gasol, J. M., Gismervik, I., et al. (2006). A comparative study of responses in plankton food web structure and function in contrasting European coastal waters exposed to experimental nutrient addition. Limnol. Oceanogr. 51, 488-503. doi: 10.4319/lo.2006.51.1_part_2.0488

Olsen, Y., Andersen, T., Gismervik, I., and Vadstein, O. (2007). Protozoan and metazoan zooplankton-mediated carbon flows in nutrient-enriched coastal planktonic communities. Mar. Ecol. Prog. Ser. 331, 67-83. doi: $10.3354 /$ meps331067

Passow, U., and Carlson, C. A. (2012). The biological pump in a high CO2 world. Mar. Ecol. Prog. Ser. 470, 249-271. doi: 10.3354/meps09985

Passow, U., and De La Rocha, C. L. (2006). Accumulation of mineral ballast on organic aggregates. Glob. Biogeochem. Cycles 20:GB1013. doi: 10.1029/2005GB002579

Paul, A. J., Bach, L. T., Schulz, K.-G., Boxhammer, T., Czerny, J., Achterberg, E. P., et al. (2015). Effect of elevated $\mathrm{CO}_{2}$ on organic matter pools and fluxes in a summer Baltic Sea plankton community. Biogeosciences 12, 6181-6203. doi: 10.5194/bg-12-6181-2015

Ploug, H., Iversen, H. M., and Fischer, G. (2008). Ballast, sinking velocity, and apparent diffusivity within marine snow and zooplankton fecal pellets: Implications for substrate turnover by attached bacteria. Limnol. Oceanogr. 53, 1878-1886. doi: 10.4319/lo.2008.53.5.1878

Pondaven, P., Gallinari, M., Chollet, S., Bucciarelli, E., Sarthou, G., Schultes, S., et al. (2007). Grazing-induced changes in cell wall silicification in a marine diatom. Protist 158, 21-28. doi: 10.1016/j.protis.2006.09.002

Quéguiner, B. (2013). Iron fertilization and the structure of planktonic communities in high nutrient regions of the Southern Ocean. Deep Sea Res. Part II Top. Stud. Oceanogr. 90, 43-54. doi: 10.1016/j.dsr2.2012.07.024

Ragueneau, O., Dittert, N., Pondaven, P., Tréguer, P., and Corrin, L. (2002). Si/C decoupling in the world ocean: is the Southern Ocean different? Deep Sea Res. II 49, 3127-3154. doi: 10.1016/S0967-0645(02)00075-9

Ragueneau, O., Savoye, N., Del Amo, Y., Cotten, J., Tardiveau, B., and Leynaert, A. (2005). A new method for the measurement of biogenic silica in suspended matter of coastal matter: using Si:Al ratios to correct for the mineral interference. Cont. Shelf Res. 25, 697-710. doi: 10.1016/j.csr.2004. 09.017

Rynearson, T. A., Richardson, K., Lampitt, R. S., Sieracki, M. E., Poulton, A. J., Lyngsgaard, M. M., et al. (2013). Major contribution of diatom resting spores to vertical flux in the sub-polar North Atlantic. Deep Sea Res. Part Oceanogr. Res. Pap. 82, 60-71. doi: 10.1016/j.dsr.2013.07.013

Sanders, R., Henson, S. A., Koski, M., Christina, L., Painter, S. C., Poulton, A. J., et al. (2014). The biological carbon pump in the North Atlantic. Prog. Oceanogr. 129, 200-218. doi: 10.1016/j.pocean.2014.05.005

Sarmiento, J. L., Dunne, J., and Armstrong, R. A. (2004). Do We now understand the ocean's biological pump? US JGOFS Newsl. 12, 1-5.

Schultes, S., Lambert, C., Pondaven, P., Corvaisier, R., Jansen, S., and Ragueneau, O. (2010). Recycling and Uptake of $\mathrm{Si}(\mathrm{OH}) 4$ when Protozoan Grazers Feed on Diatoms. Protist 161, 288-303. doi: 10.1016/j.protis.2009.10.006

Shanks, A. L., and Trent, J. D. (1980). Marine snow: sinking rates and potential role in marine flux. Deep Sea Res. I 27, 137-144. doi: 10.1016/0198-0149(80) 90092-8

Siegel, D. A., Buesseler, K. O., Behrenfeld, M. J., Benitez-Nelson, C. R., Boss, E., Brzezinski, M. A., et al. (2016). Prediction of the export and fate of global ocean net primary production: the EXPORTS science plan. Front. Mar. Sci. 3:22. doi: $10.3389 /$ fmars. 2016.00022

Smetacek, V. (1985). Role of sinking in diatom life history cycles: ecological, evolutionary and geological significance. Mar. Biol. 84, 239-251. doi: 10.1007/BF00392493

Sommer, F., Saage, A., Santer, B., Hansen, T., and Sommer, U. (2005). Linking foraging strategies of marine calanoid copepods to patterns of nitrogen stable isotope signatures in a mesocosm study. Mar. Ecol. Prog. Ser. 286, 99-106. doi: 10.3354/meps 286099

Sommer, U., Hansen, T., Stibor, H., and Vadstein, O. (2004). Persistence of phytoplankton responses to different $\mathrm{Si}$ : $\mathrm{N}$ ratios under mesozooplankton grazing pressure: a mesocosm study with Northeast Atlantic plankton. Mar. Ecol. Prog. Ser. 278, 67-75. doi: 10.3354/meps 278067 
Sommer, U., Sommer, F., Santer, B., Jamieson, C., Boersma, M., Becker, C., et al. (2001). Complementary impact of copepods and cladocerans on phytoplankton. Ecol. Lett. 4, 545-550. doi: 10.1046/j.1461-0248.2001.00263.x

Spilling, K., Schulz, K. G., Paul, A. J., Boxhammer, T., Achterberg, E. P., Hornick, T., et al. (2016). Effects of ocean acidification on pelagic carbon fluxes in a mesocosm experiment. Biogeosciences 13, 6081-6093. doi: 10.5194/bg-13-6081-2016

Stange, P., Bach, L. T., Le Moigne, F. A., Taucher, J., Boxhammer, T., and Riebesell, U. (2017). Quantifying the time lag between organic matter production and export in the surface ocean: implications for estimates of export efficiency. Geophys. Res. Lett. 44, 268-276. doi: 10.1002/2016GL0 70875

Stibor, H., Vadstein, O., Lippert, B., Roederer, W., and Olsen, Y. (2004). Calanoid copepods and nutrient enrichment determine population dynamics of the appendicularian Oikopleura dioica: a mesocosm experiment. Mar. Ecol. Prog. Ser. 270, 209-215. doi: 10.3354/meps 270209

Svensen, C., Egge, J. K., and Stiansen, J. E. (2001). Can silicate and turbulence regulate the vertical flux of biogenic matter? a mesocosm study. Mar. Ecol. Prog. Ser. 217, 67-80. doi: 10.3354/meps 217067

Svensen, C., Nejstgaard, J. C., Egge, J. K., and Wassmann, P. (2002). Pulsing versus constant supply of nutrients (N, P and Si): effect on phytoplankton, mesozooplankton and vertical flux of biogenic matter. Sci. Mar. 66, 189-203. doi: 10.3989/scimar.2002. $66 n 3189$

Turner, J. T. (2015). Zooplankton fecal pellets, marine snow, phytodetritus and the ocean's biological pump. Prog. Oceanogr. 130, 205-248. doi: $10.1016 /$ j.pocean.2014.08.005
Utermöhl, H. (1958). Zur Vervollkommnung der quantitativen Phytoplanktonmethodik. Mitteilungen Int. Vereiningung F,r Theor. Angew. Limnol. 9, 1-38.

Vadstein, O., Stibor, H., Lippert, B., Løseth, K., Roederer, W., Sundt-Hansen, L., et al. (2004). Moderate increase in the biomass of omnivorous copepods may ease grazing control of planktonic algae. Mar. Ecol. Prog. Ser. 270, 199-207. doi: $10.3354 /$ meps 270199

van Marion, P., (1996). Ecological studies in Hopavågen, A Landlocked Bay at Agdenes. Sør-Trøndelag: NTNU Vitenskapsmuseet.

Wassmann, P., Egge, J. K., Reigstad, M., and Aksnes, D. L. (1996). Influence of dissolved silicate on vertical flux of particulate biogenic matter. Mar. Pollut. Bull. 33, 10-21. doi: 10.1016/S0025-326X(97)00130-6

Conflict of Interest Statement: The authors declare that the research was conducted in the absence of any commercial or financial relationships that could be construed as a potential conflict of interest.

The reviewer JT and handling Editor declared their shared affiliation.

Copyright (c) 2018 Moriceau, Iversen, Gallinari, Evertsen, Le Goff, Beker, Boutorh, Corvaisier, Coffineau, Donval, Giering, Koski, Lambert, Lampitt, Le Mercier, Masson, Stibor, Stockenreiter and De La Rocha. This is an open-access article distributed under the terms of the Creative Commons Attribution License (CC $B Y)$. The use, distribution or reproduction in other forums is permitted, provided the original author(s) and the copyright owner are credited and that the original publication in this journal is cited, in accordance with accepted academic practice. No use, distribution or reproduction is permitted which does not comply with these terms. 